\title{
Nesting interactions of the social wasp Dolichovespula saxonica [F.] (Hymenoptera: Vespinae) in wooden nest boxes for birds in the forest reserve „Las Piwnicki” in the Chełmno Land (Northern Poland)
}

\author{
*Tadeusz Pawlikowski, **Krzysztof Pawlikowski \\ *Laboratory for Biomonitoring of Terrestrial Environments, Institute of Ecology \& Environmental Protection, \\ Nicolaus Copernicus University, Gagarina 9,87-100 Toruń, Poland, e-mail: pawlik@biol.uni.torun.pl \\ **Sea Fisheries Institute in Gdynia, Department of Fisheries Oceanography and Marine Ecology, \\ Kollataja 1, 81-332 Gdynia, Poland, e-mail: k.pawlikowski@beebase.uni.torun.pl
}

\begin{abstract}
The aim of this research was to investigate the process of colonization in wooden nest boxes for birds by the wasp Dolichovespula saxonica $[\mathrm{F}$.] in the forest reserve "Las Piwnicki" during 1986-1987. About 69\% of 150 nest boxes were colonized (36\% by $D$. saxonica) in 1986 and 35\% (10\% by D. saxonica) in 1987. Parasite Shecophaga vesparum Court was observed inside small cell nests (SC) and large cell nests (LC) in the ratio of $5(\mathrm{SC}): 3$ (LC). During the two seasons, the decrease in the number of parasited nests followed with the ratio of 10(1986) : 1(1987). Competition of the „wasp - wasp” type (VV) compared to other competition types, such as „wasp - bird” (VA) and different types with wasps (DT), was the most frequent one among the interactions and followed with the ratio $1(\mathrm{VV}): 7(\mathrm{VA}): 5(\mathrm{DT})$. The number and proportions of construction types of nests during the studied growing seasons seem to prove the regular and irregular development of the Dolichovespula saxonica colony.
\end{abstract}

Key words: Hymenoptera, Vespinae, Dolichovespula saxonica, interactions, the Forest Reserve "Las Piwnicki".

\section{Introduction}

Saxon wasp - Dolichovespula saxonica [F.] dominates in number among species of social wasps from the genus Dolichovespula. In Poland it takes place mainly in forest areas (unpublished data). Similarly to other social wasps, this species is one of the very active predators, hunting insects, including mainly imagines of dipterans (Diptera). Its successful development is attributed to habitual building of nests in hollows and other surface, wooden shelters (Edwards 1980; Kemper \& Döhring 1967).

Introduction of wooden nest boxes for birds in forest areas provides the species with new nesting sites. Efficiency in colonising those nesting sites is a result of competition for the sites by different species of birds, mammals and invertebrates, including wasps of the same species and other social wasps. Whereas, effectiveness of the development of wasp colonies remains under the influence of mechanisms of intrapopulation competition (Archer 1998) and the parasitoid Shecophaga vesparum Court (Hymenoptera: Ichneumonidae) (Edwards 1980; Matsuura \& Yamane 1990).

In 1992-1994, the efficiency in colonising ca. 240 birds' wooden nest boxes by the wasp Dolichovespula saxonica had been observed in typical forest environments of Borecka Forest (Pawlikowski \& Pawlikowski 2003). The present paper aims at evaluating the effectiveness of settling in about 150 boxes by the wasp Dolichovespula saxonica in the forest reserve of northern Poland, taking 


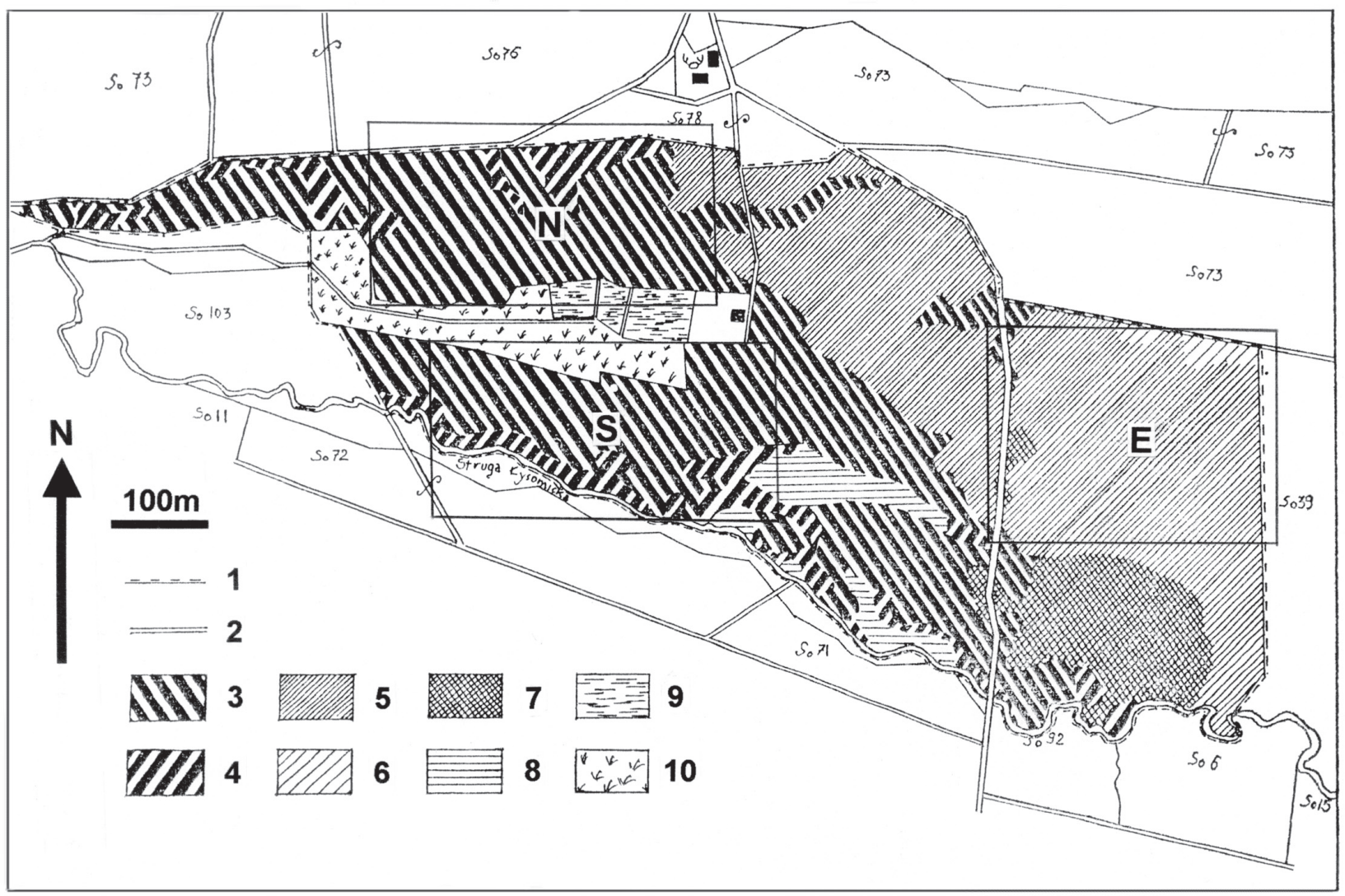

Figure 1. Location of areas with wasp settlements inside wooden nest boxes for birds (N, S, E) in the Reserve "Las Piwnicki": 1 - boundary, 2 - roads, 3 - Tilio-Carpinetum typicum, 4 - Tilio-Carpinetum stachyetosum, 5 - Querco-Pinetum, 6 - Querco-Pinetum strongly resembling a pine forest, 7 - Querco-Pinetum mixed with Tilio-Carpinetum, 8 - Circeo-Alnetum, 9 - ponds, 10 - meadows (Gromadska 1977, after Rejewski 1977)

into account interactions of other species. At the same time, the development success of colonies was subject to evaluation, as well as the extent of their parasitation by Shecophaga vesparum.

\section{Material and methods}

The research was carried out in 1986-1987 in the Forest Reserve „Las Piwnicki” on the northern edge of the Torun Basin within the lower Vistula valley (North Poland, UTM: CD38). The whole area is slightly inclined towards the west and diversified with two parallely situated dune embankments of the relative height ranging from 3 to $5 \mathrm{~m}$. Along the southern edge, a small rivulet, called the Łysomicka Stream flows (Fig. 1).

The dominating forest associations are mesotrophic mixed lime-oak-hornbeam forest - Tilio-Carpinetum typicum, fertile mixed lime-oak-hornbeam forest - Tilio-Carpinetum stachyetosum and mixed coniferous forest - Pino Quercetum (Rejewski 1977). Mesotrophic mixed lime-oak- hornbeam forest is most developed in the central and northwestern part of the reserve. This forest consists of a higher layer of trees composed of 300-year-old pedunculate oaks (Quercus robur L.) and a lower layer of undergrowth dominated by hornbeam (Carpinus betulus L.). In the herb layer, mainly species of mixed lime-oak-hornbeam forest occur, accompanied by pine forest species.

Fertile mixed lime-oak-hornbeam forest covers lower locations in the western and southwestern part of the reserve. Also there, the tree stand consists of two layers. In the upper layer, hornbeam is the most significant species and is accompanied by pedunculate oak and black alder (Alnus glutinosa L.). In the understory hornbeam dominates, and in some places hazel (Corylus avellana L.) and common elder (Sambucus nigra L.). The herb layer is highly diversified with some contribution of riparian forest vegetation.

Mixed coniferous forest occurs in the northeastern part of the reserve. The higher tree stand consists mainly of pine (Pinus sylvestris L.) and pedunculate oak, and the lower one is mainly dominated by the undergrowth of 
Table 1. Wooden nest boxes settling status in research areas in the reserve "Las Piwnicki" (RLP): NA - north area in Tilio-Carpinetum typicum forest, SA - south area in Tilio-Carpinetum typicum \& stachyetosum forest, EA - east area in Querco-Pinetum forest, $\mathrm{nb}$ - number of boxes

\begin{tabular}{|c|c|c|c|c|c|c|c|c|c|c|c|}
\hline \multirow{3}{*}{\multicolumn{2}{|c|}{ Settling }} & \multicolumn{5}{|c|}{1986} & \multicolumn{5}{|c|}{1987} \\
\hline & & \multirow{2}{*}{$\begin{array}{c}\mathrm{NA} \\
\mathrm{nb}=58\end{array}$} & \multirow{2}{*}{$\begin{array}{c}\mathrm{SA} \\
\mathrm{nb}=44\end{array}$} & \multirow{2}{*}{$\frac{\mathrm{EA}}{\mathrm{nb}=47}$} & \multicolumn{2}{|c|}{ RLP } & \multirow{2}{*}{$\begin{array}{c}\mathrm{NA} \\
\mathrm{nb}=56\end{array}$} & \multirow{2}{*}{$\begin{array}{c}\mathrm{SA} \\
\mathrm{nb}=44\end{array}$} & \multirow{2}{*}{$\begin{array}{c}\mathrm{EA} \\
\mathrm{nb}=47\end{array}$} & \multicolumn{2}{|c|}{ RLP } \\
\hline & & & & & $\mathrm{nb}=149$ & $\% \mathrm{nb}$ & & & & $\mathrm{nb}=147$ & $\% \mathrm{nb}$ \\
\hline \multicolumn{2}{|l|}{ Bird } & 19 & 14 & 11 & 44 & 29.5 & 17 & 9 & 9 & 35 & 23.8 \\
\hline \multicolumn{2}{|l|}{ Bird + Bombus } & - & - & 1 & 1 & 0.6 & - & - & 1 & 1 & 0.6 \\
\hline \multirow{3}{*}{$\begin{array}{l}\text { Dolichovespula } \\
\text { saxonica }[\mathrm{F} .]\end{array}$} & QN & 7 & 1 & - & 8 & 5.3 & 5 & 5 & - & 10 & 6.8 \\
\hline & $\mathrm{SC}+\mathrm{P}$ & 1 & - & 3 & 4 & 2.6 & 2 & - & 1 & 3 & 2.0 \\
\hline & $\mathrm{LC}+\mathrm{P}$ & - & 1 & 3 & 4 & 2.6 & - & - & - & - & - \\
\hline \multirow[t]{2}{*}{ D.saxonica + wasp } & QN & 1 & - & 2 & 3 & 2.0 & - & - & - & - & - \\
\hline & $\mathrm{SC}+\mathrm{P}$ & 3 & - & - & 3 & 2.0 & - & - & - & - & - \\
\hline \multirow[t]{3}{*}{ D.saxonica + bird } & QN & 8 & 7 & 6 & 21 & 14.1 & 1 & 1 & - & 2 & 1.3 \\
\hline & $\mathrm{SC}+\mathrm{P}$ & 1 & 1 & 3 & 5 & 3.3 & - & - & - & - & - \\
\hline & $\mathrm{LC}+\mathrm{P}$ & 1 & - & 4 & 5 & 3.3 & - & - & - & - & - \\
\hline \multirow[t]{2}{*}{ Vespa crabro L. } & QN & 1 & - & 3 & 4 & 2.6 & 1 & - & - & 1 & 0.6 \\
\hline & $\mathrm{SC}$ & - & - & 1 & 1 & 0.6 & - & - & - & - & - \\
\hline \multicolumn{2}{|l|}{ Not seetling } & 16 & 20 & 10 & 46 & 30.8 & 30 & 29 & 36 & 95 & 64.6 \\
\hline
\end{tabular}

$\mathrm{QN}$ - queen nest

$\mathrm{SC}$ - nest with small cells

LC - nest with large cells

$+\mathrm{P}-$ nest parasitized by Sphecophaga vesparum Court

hornbeam, pedunculate oak and buckthorn (Frangula alnus Mill.). The herb layer is characterized by sparse contribution of species.

The Reserve remains under the influence of atlantic and continental climate. Mean annual temperature for this area oscillates around $6^{\circ} \mathrm{C}$. Usual amplitudes of temperature are from -12 to $4^{\circ} \mathrm{C}$ in January and from 16 to $21^{\circ} \mathrm{C}$ in July. Precipitation oscillates from $300 \mathrm{~mm}$ to $800 \mathrm{~mm}$ per year (Barcikowski et al. 1990). Air temperature and total precipitation of growing seasons during the studied years were favourable for the development of the social wasps' colony.

For the studies on colonization of nest boxes, three sites with different forest communities were selecte. A list of colonised boxes in particular years is presented in Table 1 .

Altogether 149 birds' wooden nest boxes were used; type A1, B1 and C1 according to Sokołowski (1971). In the autumn 1986 about 50 boxes were installed at each site (each type proportionally represented), 2-3 $\mathrm{m}$ above the ground. Colonization status of boxes has been inspected at the end of May, at the beginning, middle and end of July, in mid August, as well as at the beginning or mid September every research year. While inspecting the breeding boxes, their settlement status was recorded, and colonizing species were determined. Nests of wasps, in which the colonial development was completed, were collected for detailed analysis of settlement in cells. In total 67 nests were collected, including 53 in 1986 and 14 in 1987. During the last inspection in each research year, breeding boxes were cleaned up from all other remained nests (mainly birds'), as well as from organic remains.

\section{Results}

Effectiveness of settlement in nearly 150 wooden nest boxes for birds at 3 forest sites of the reserve "Las Piwnicki" in 1986-1987 is presented in Table 1. Their inhabitation level were $69 \%$ (including $36 \%$ by Dolichovespula saxonica) in 1986 and $35 \%(10 \%)$ in 1987. Saxon wasp colonized the breeding boxes independently (S), as well as together with 
Table 2. Nests of the Dolichovespula saxonica in research areas in the reserve "Las Piwnicki" in 1986-1987; area marks as in Table 1

\begin{tabular}{|c|c|c|c|c|c|c|c|c|c|c|c|c|c|c|c|c|}
\hline \multirow{4}{*}{$\begin{array}{c}\text { Nest } \\
\text { development } \\
\text { types }\end{array}$} & \multicolumn{16}{|c|}{ Number of nests $[\mathrm{n}]$ in research areas } \\
\hline & \multicolumn{8}{|c|}{1986} & \multicolumn{8}{|c|}{1987} \\
\hline & \multicolumn{2}{|c|}{ NA } & \multicolumn{2}{|c|}{ SA } & \multicolumn{2}{|c|}{ EA } & \multicolumn{2}{|c|}{ RLP } & \multicolumn{2}{|c|}{ NA } & \multicolumn{2}{|c|}{ SA } & \multicolumn{2}{|c|}{ EA } & \multicolumn{2}{|c|}{ RLP } \\
\hline & $\mathrm{n}$ & $\%$ & $\mathrm{n}$ & $\%$ & $\mathrm{n}$ & $\%$ & $\mathrm{n}$ & $\%$ & $\mathrm{n}$ & $\%$ & $\mathrm{n}$ & $\%$ & $\mathrm{n}$ & $\%$ & $\mathrm{n}$ & $\%$ \\
\hline QN & 16 & 72.7 & 8 & 80.0 & 8 & 38.1 & 32 & 60.3 & 6 & 75.0 & 6 & 100 & - & - & 12 & 85.7 \\
\hline $\mathrm{SC}+\mathrm{P}$ & 5 & 22.7 & 1 & 10.0 & 4 & 19.0 & 10 & 18.9 & 2 & 25.0 & - & - & - & - & 2 & 14.3 \\
\hline $\mathrm{SCM}+\mathrm{P}$ & - & - & - & - & 2 & 9.5 & 2 & 3.8 & - & - & - & - & - & - & - & - \\
\hline $\mathrm{LCfQM}+\mathrm{P}$ & 1 & 4.5 & - & - & 4 & 19.0 & 5 & 9.4 & - & - & - & - & - & - & - & - \\
\hline $\mathrm{LCQM+P}$ & - & - & 1 & 10.0 & 3 & 14.3 & 4 & 7.5 & - & - & - & - & - & - & - & - \\
\hline All nests & 22 & 100 & 10 & 100 & 21 & 100 & 53 & 100 & 8 & 100 & 6 & 100 & - & - & 14 & 100 \\
\hline
\end{tabular}

QN - nests built by founder queens

$\mathrm{SC}$ - nests with small cells produced

SCM - nests with small cells and males produced

LCfQM - nests with large cells males and a few queens produced

LCQM - nests with large cells and queens and males produced

$+\mathrm{P}-$ nests parasitized by Sphecophaga vesparum

other species (X). Moreover, also birds (A: mainly great tit - Parus major L. and pied flycatcher - Ficedula hypoleuca (Pall.) and hornet - Vespa crabro L. (C) participated in the settlement. Settlement contribution for A : S : X : C was represented in the following proportions $9: 3: 7: 1$ in 1986 and $7: 2: 0.4: 0.2$ in 1987.

Contribution of saxon wasp in the settlement process in breeding boxes was clearly corelated to the two-year cyclical development of families according to the Archer's principle (1998). In accordance with the aforementioned principle, after a season with a high number of females (including mainly new queens in nests with large cells), a season with a small number of females follows. Research on the structural variability in communities of social wasps, in the Toruń Basin (Pawlikowski \& Przybylska 2001) and in the Kujawy region (Pawlikowski \& Pawlikowski 2006), proved the synchronization between seasons with a high number of females and even-number years. Assuming this as a regularity for populations of social wasps from Northern Poland, one can validate a higher contribution of nests in the reserve during a season of an even-number year. Contribution of nests, which completed their development at the stage of queens' nests (QN) or nests with small cells (SC), or nests with large cells (LC) was expressed in the ratio of $8: 3: 1$ in 1986 and $6: 1: 0$ in 1987 .

Only nests with small (SC) and large (LC) cells, i.e. $14-62 \%$ of all nests of Dolichovespula saxonica were subject to parasitation by Shecophaga vesparum. Nests with small cells were more parasited than nests with large cells, in the ratio of $5(\mathrm{SC}): 3(\mathrm{LC})$. The effect of parasitation was not high and included 3-5\% of specimens in SC nests and $0.4-4 \%$ of specimens in LC nests. The number of parasited nests was decreasing in particular years, following the numerical ratio of 10(1986) : 1(1987) (Tab. 3).

Competition for birds' wooden nest boxes at the studied sites of the Reserve comprised 7 interactive types with participation of wasps, bumblebees and birds (Tab. 4). The interactive types were basically revealed between wasps (VV), between wasps and birds (VA), as well as between other types (DT). Contribution of those types for VV : VA : DT in particular years was as follows: in $1986-1: 6: 3$, in 1993, in $1987-0: 1: 6$; whereas for the whole study period $-1: 7: 5$.

\section{Discussion}

The balance of nests and types of interaction in the reserve and in the Borecka Forest (Pawlikowski \& Pawlikowski 2003) was used in order to determine the nest development types in normal and abnormal development cycle. A cycle was regarded as normal when consisted of a sequence of organizational events with participation of a colony's founder queen and few generations of workers that walked out generations of males and young queens. A cycle was regarded as abnormal if an initial nest was orphaned during that cycle, as a consequence of competition between posthibernation queens. Further development of an orphaned 
Table 3. Competition $(\leftrightarrow)$ for wooden nest boxes for birds with wasps of Dolichovespula saxonica. Number of interactions (ni) and percentages(\% ni) within the research areas in the reserve "Las Piwnicki" in 1986-1987.

\begin{tabular}{|l|c|c|c|c|c|}
\hline \multirow{2}{*}{$\begin{array}{c}\text { Competition } \\
\text { type }\end{array}$} & \multirow{2}{*}{$\begin{array}{c}\text { Subjects of } \\
\text { interactions }\end{array}$} & \multicolumn{2}{|c|}{1986} & \multicolumn{2}{c|}{1987} \\
\cline { 3 - 6 } & ni=53 & $\%$ ni & ni=14 & $\%$ ni \\
\hline \multirow{4}{*}{ VV } & NDsx $\leftrightarrow$ 2QDsx & 1 & 1.9 & - & - \\
\cline { 2 - 6 } & NDsx $\leftrightarrow$ QDsx & 1 & 1.9 & - & - \\
\cline { 2 - 6 } & NDsx $\leftrightarrow$ NDsx & 1 & 1.9 & - & - \\
\cline { 2 - 6 } & NDsx $\leftrightarrow$ NVc & 2 & 3.7 & - & - \\
\hline VA & NDsx $\leftrightarrow$ NA & 1 & 1.9 & - & - \\
\hline AV & InA $\leftrightarrow$ NDsx & 32 & 58.5 & 2 & 14.3 \\
\hline A?V & InA? $\leftrightarrow$ NDsx & 15 & 28.3 & 12 & 85.7 \\
\hline
\end{tabular}

$\mathrm{N}=$ nest, $\mathrm{In}=$ initial nesting, $\mathrm{Q}=$ queen, $\mathrm{A}=$ bird, $\mathrm{A}$ ? = probably bird, $\mathrm{V}=$ Vespinae wasp species, $\mathrm{B}=$ Bombus sp., Dsx $=$ Dolichovespula saxonica,, $\mathrm{Vc}=$ Vespa crabro
Table 4. Parasitize efect of Dolichovespula saxonica nests by Sphecophaga vesparum in forest areas of the reserve "Las Piwnicki" in 1986-1987; nests types as in Tab. 2.

\begin{tabular}{|l|c|c|c|c|r|c|}
\hline \multicolumn{2}{|c|}{ Nests } & \multicolumn{4}{c|}{ Number of individuals in nest } \\
\hline \multirow{2}{*}{ Type } & \multirow{2}{*}{ Number } & \multicolumn{2}{|c|}{ all in cells } & \multicolumn{3}{c|}{ parasited } \\
\cline { 4 - 8 } & & range & mean & range & mean & $\begin{array}{c}\% \text { of } \\
\text { all }\end{array}$ \\
\hline SC & 12 & $16-206$ & 48.7 & $1-8$ & 2.3 & 4.7 \\
\hline SCM & 2 & $106-244$ & 175.0 & $1-9$ & 5.0 & 2.9 \\
\hline LCfQM & 5 & $222-376$ & 288.6 & $1-22$ & 11.6 & 4.0 \\
\hline LCQM & 4 & $221-1262$ & 889.3 & $1-8$ & 3.3 & 0.4 \\
\hline
\end{tabular}

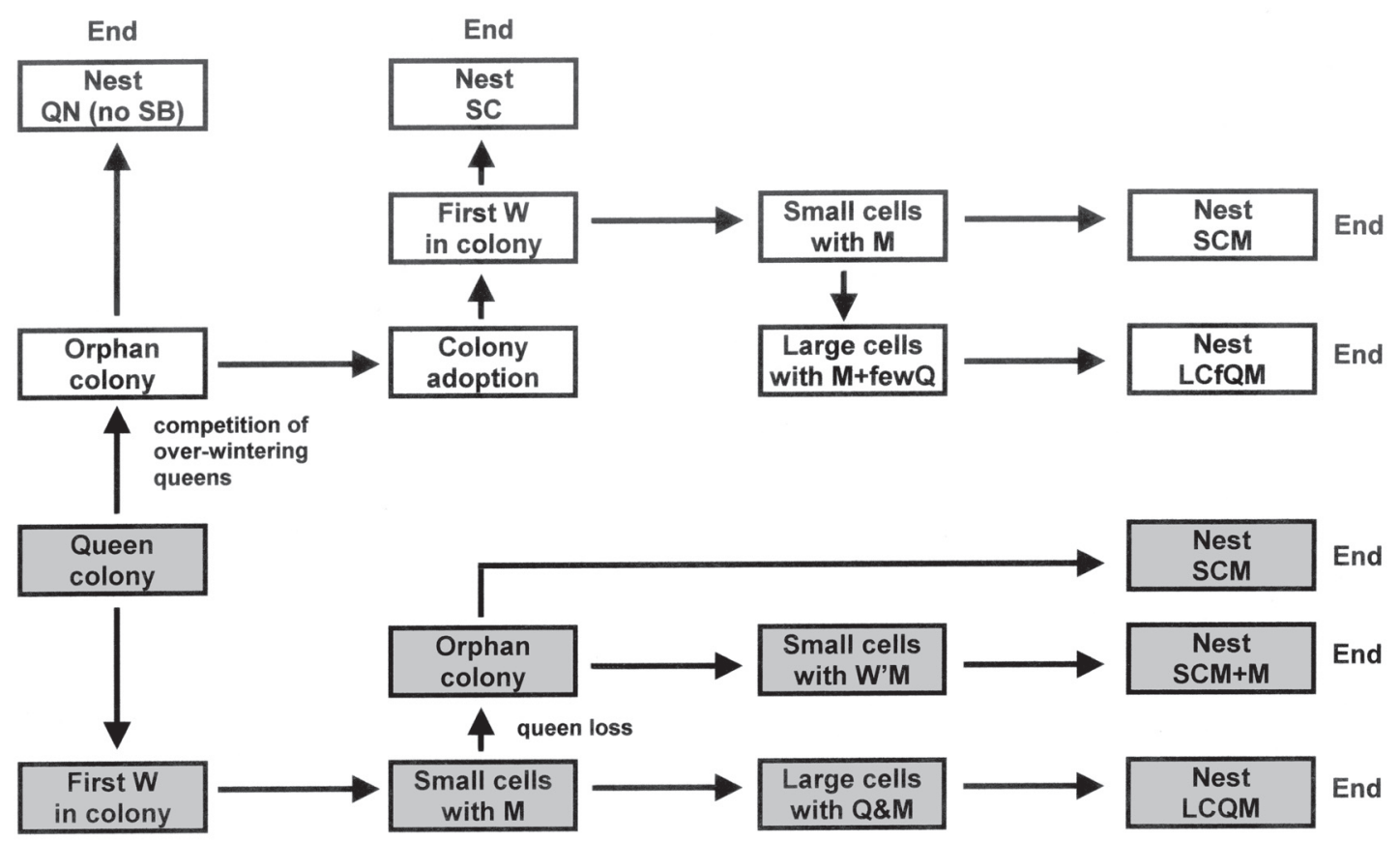

Figure 2. The normal and abnormal colonial development of Dolichovespula saxonica when founded queens are fertilized. Normal colonial development are shaded. Explanations: SB - siled brood, W - workers, M - males, W'M -worker's males, Q queens; types of nests explaned in text 
colony proceeded with the presence of a queen-usurper and few generations of workers, which produce scanty generations of males and young queens (Fig. 2).

The highest number of nests was recorded during the even-number years. During those years, queens' nests (QN) and nests with small cells (SC) dominated over nests with large cells (LC). Also then, interactions between queens were recorded always and quite frequently during nest founding. The number and proportions of nest development types of nests during the studied growing seasons seem to prove the regular and irregular development of the Dolichovespula saxonica colony. One should observ, that during the seasons with intensive competition between queens, all nest development types appear, developed through normal and abnormal development of the colony. Nevertheless, nests with abnormal development of the colony dominated among them. Also, during the years without intensive competition between queens, all nest development types occurred, but nests that originated as a result of regular development of the colony dominated than.

Parasitation by Sphecophaga vesparum, which accompanied particular developmental types of the colony, was not high. In the general balance of produced wasps, the observed parasitation did not significantly influence the course and the intensity of the life cycle of the wasp Dolichovespula saxonica.

\section{References}

Archer M. E., 1998, A lifetime with wasps (Hymenoptera: Vespinae), Naturalist 123: 3-14.

Barcikowski A., Nienartowicz A., Wilkoń-Michalska J. \& Wójcik G., 1990, Dynamika struktury fitocenoz w rezerwacie "Las Piwnicki” koło Torunia w latach 19701990 [A stucture dynamic of phytocenoses in Reserve "Las Piwnicki" near Toruń in 1970-1990], [in:] Taktyka adaptacyjna populacji i biocenoz poddanych antropopresji [Adaptive tactics of populations and biocenoses subject to anthropopressure], Wyd. SGGWAR, Warszawa 42: 1-13.

Edwards R., 1980, Social wasps, Their biology and control, Rentokil Ltd., East Grinstead.

Gromadska M., 1977, Zagadnienia produktywności lasu mieszanego w rezerwacie "Las Piwnicki” koło Torunia
[The problems of productivity of the mixed forest in the reserve "Las Piwnicki" near Toruń], Acta Universitatis Nicolai Copernici, Biologia 19, Nauki Mat.-Przyr. 39: 7-14.

Kemper H. \& Dőhring E., 1967, Die sozialen Faltenwespen Mitteleuropas, Verlag Paul Parey, Berlin - Hamburg.

Matsuura M. \& Yamane S., 1990, Biology of the Vespinae wasps, Springer-Verlag, Berlin-London-Tokyo.

Pawlikowski T. \& Osmański M., 1998, Atrakcyjność środowisk miejskich dla os społecznych (Hymenoptera: Vespinae) na obszarze Torunia [Attractiveness of city environments for social wasps (Hymenoptera: Vespinae) in the area of Toruń], Wiadomości Entomologiczne, 17(2): 95-104.

Pawlikowski T. \& Przybylska E., 2001, Dynamika zmian struktury zespołu os społecznych (Hymenoptera: Vespinae) na obszarze Torunia w latach 1979-1995 [Dynamic of structure changes of social wasp (Hymenoptera: Vespinae) community in town area of Toruń during 1979-1995], Bioróżnorodność i ekologia populacji zwierzęcych w środowiskach zurbanizowanych [Biodiversity and ecology of animal populations in urban environments],Uniwersytet Przyrodniczo-Techniczny, Bydgoszcz: 94-101.

Pawlikowski T. \& Pawlikowski K., 2003, Zasiedlanie drewnianych skrzynek lęgowych dla ptaków przez osę saksońską Dolichovespula saxonica (F.) (Hymenoptera: Vespidae) w Puszczy Boreckiej [Wasp Dolichovespula saxonica (F.) (Hymenoptera: Vespidae) from wooden nest boxes for birds in the Borecka Forest], Wiadomości Entomologiczne 22(4): 201-210.

Pawlikowski T. \& Pawlikowski K., 2006, Long-term dynamics of structure changes of the social wasp community (Hymenoptera: Vespinae) in agricultural landscape of the Kujawy Region, Ecological Questions 7: 21-28.

Rejewski M., 1977, Zbiorowiska roślinne rezerwatu "Las Piwnicki" [Plant communities of the Reserve "Las Piwnicki"], Acta Universitatis Nicolai Copernici, Biologia 19, Nauki Mat.-Przyr. 39: 67-79.

Sokołowski L., 1971, Poradnik ochrony ptaków [General information about birds protection], Wyd. LOP, Warszawa. 